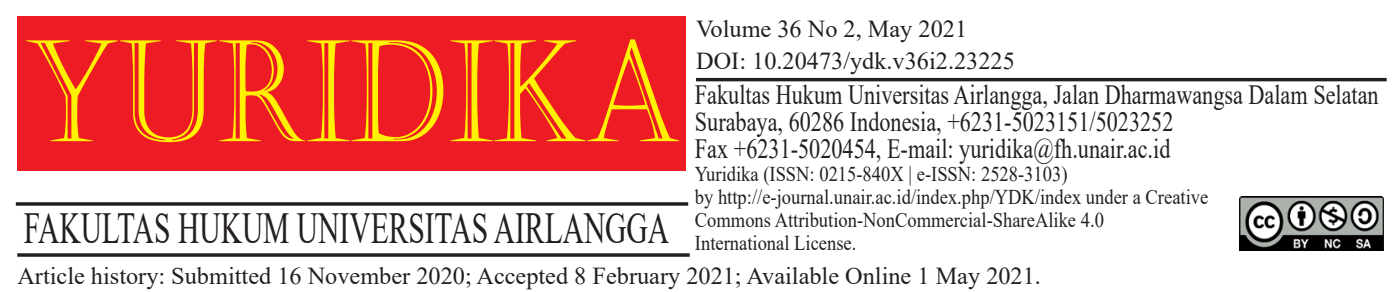

\title{
Criminal Law Aspect of Illegal Transshipment Under Act Number 45 of 2009 Concerning Fisheries
}

\author{
Herman, Oheo K.Haris and Syahbudin \\ man.herman76@uho.ac.id \\ University of Halu Oleo
}

\begin{abstract}
This study aims to analyze the practice of illegal transshipment in compliance with Act Number 45 of 2009 criminal provisions law concerning Fisheries, using legal concept, law, and case approaches. Nowadays, there are various operational modes of fish theft, with poor regulations that maximally accommodate crimes related to fisheries by perpetrators. Therefore, due to its unsustainability and economic loss, the fisheries and marine sector in Indonesia has to improve its performance. The results show that illegal transshipment engages some elements contained in Article 94 and 94A of Act Number 45 of 2009 which was an amendment of Act Number 31 of 2004. According to article 94, when a fishing vessel is caught transferring shipment in the middle of a high sea without in possession of a license called SIKPI, its owner/s are sentenced to 5-years imprisonment with a one billion five hundred million rupiah fine. Meanwhile, according to Article 94A, when a fishing vessel is caught using fake licenses such as SIUP, SIPI, and SIKPI, its owners are sentenced to 7 years imprisonment with a fine of three billion rupiahs.
\end{abstract} Keywords: Criminal Law; Illegal Transshipment; Fisheries.

\section{Introduction}

Indonesia is an archipelagic country with two-thirds of its territory covered by water. ${ }^{1}$ A long time ago, the international communities called referred to it by various name before the inception of "The Republic of Indonesia" due to its archipelagic location. For example, the Chinese called it Nan-hai (South Sea Islands), the Indians - Dwipantara (Land Across Archipelago), the Arabs named it jaza'ir al-Jawi (the islands of Java), while the European nations called it the Indian Island. ${ }^{2}$

1 Agustina Soebachman, Sejarah Nusantara Berdasarkan Urutan Tahun (Surya Media Utama 2014).[14].

2 Esty Hayu Dewanty R.K, 'Rules of Origin Sebagai Instrumen Penanganan Praktik Illegal Transhipment' (2012) 7 Yuridika <https://e-journal.unair.ac.id/YDK/article/view/294>.[3]. 
Geographically, the water areas which cover almost $70 \%$ of Indonesia's territory contain extraordinary marine wealth, ranging from fishes, transportation, industrial services, and tourism. ${ }^{3}$ However, the greatest potential of marine biological resources is fisheries, with sea exploration activities capable of triggering criminal activities. According to the Food and Agriculture Organization (FAO) ${ }^{4}$ fishery criminal activities are Illegal, Unregulated, and Unreported Fishing (IUU-Fishing). Based on data from the Ministry of Maritime Affairs and Fisheries, among the 14 fishing zones all over the world, only 2 are vulnerable one of which is in Indonesia. ${ }^{5}$

In addition, the zones in highly vulnerable to-IUU fishing are the Malacca, Java, Arafuru, Timor, Banda Seas, and the waters around Maluku and Papua. ${ }^{6}$ This tends to weaken the management of fisheries resources, in several areas (WPP) as they experience overfishing. ${ }^{7}$ Initially, Act Number 9 of 1985 regulated this industry. However, after ratifying the 1982 United Nations Convention on the Law of the Sea (UNCLOS) on the Act Number 17 of 1982, the country had the right to properly utilize, conserve, and manage fish resources in its Economic Zone or Zona Ekonomi Ekslusif, with the implemented of international standards and regulations. ${ }^{8}$ With the enactment of the 1982 UNCLOS, Indonesia was recognized as an archipelagic state on November 16, 1994. This convention stated that the sea is a very important entity for the present and future existence of Indonesia since it is the raison d'être (the reason for existence) as an archipelagic country. ${ }^{9}$

Besides, the consideration of Act Number 32 of 2014 concerning Maritime Affairs stated that marine management should follow the national development

\footnotetext{
${ }^{3}$ Kementerian Kelautan dan Perikanan Republik Indonesia, Laporan Kementerian Kelautan Dan Perikanan Republik Indonesia (Sekretaris Jenderal KKP RI 2014).[17].

${ }^{4}$ FAO, IUU Fishing Dalam Code of Conduct For Responsible Fisheries (FAO 1995).

${ }^{5}$ Tommy Sihotang, 'Masalah Illegal, Unregulated, UnreportedFishing Dan Penanggulangannya Melalui Pengadilan Perikanan’ (2005) 4 Jurnal Keadilan.[58].

${ }^{6}$ Forum Keadilan, Kejutan Di Bulan April, Forum Nomor 50115-21 (2008).[41].

${ }^{7}$ Dina Sunyowati, Port State Measures Dalam Upaya Pencegahan Terhadap IUU Fishing Di Indonesia, Peran Hukum Dalam Pembangunan Di Indonesia, Liber Amicorum Prof. Dr. Etty R.Agoes,SH.,LLM (Remaja Rosdakarya 2013).[438].

${ }^{8}$ Gatot Supramono, Hukum Acara Pidana Dan Hukum Pidana Di Bidang Perikanan (Rineka Cipta 2011).[6].

${ }^{9}$ Naskah Akademik Keamanan Nasional Indonesia Aspek Maritime (Mabesal 2006).[3].
} 
interests of the population. Therefore, Indonesia's marine management need to reflect on the declaration of national sovereignty where its sustainability and stability is maintained. It also should not be exploited merely to fulfill economic needs by certain parties. However, in 2012, the Indonesia fishery production which was made up of hard/ soft-bodied animals, aquatic plants and fishes reached $72,016,061,009$ tons $^{10}$ This was mandated in Act Number 45 of 2009 Amendments to Act Number 31 of 2004 concerning Fisheries as well as other related laws and regulations. Besides this large amount of production, some foreigners and locals indulge in illegal possession of the country's marine products in various ways.

Illegal fishing activities are widely known to have various modes of operation which varies in practice and location. The perpetrators do not only try to avoid the authorities but also circumvented documents by pretending the fishing was legal. A new mode of operation currently handled by law enforcement officials is the transfer of fish shipment to other vessels in the middle of the sea. In such scenarios, they were not reporting or hiding the catches from the monitoring authorities. Such act is known as unreported fishing by the industry. ${ }^{11}$ It is also interpreted as a fishery activity which incorrectly report the catches to the competent authority. It violates the national legislation when conducted in areas of Regional Fisheries Management Organizations (RFMOs) which is not under its established reporting procedures.

The unreported fishing activities based on IPOA-IUU Fishing documents ${ }^{12}$ include:

1. Activities that are incorrectly reported to the national authorities, which are contrary to the laws and regulations;

2. Activities carried out in competence areas which have not been reported or are contrary to the specified procedures.

\footnotetext{
${ }^{10}$ KKP, 'Statistik Perikanan Tangkap Perairan Laut' $(K K P)<$ http://statistik.kkp.go.id> accessed 11 December 2021.

${ }^{11}$ Dina Sunyowati, 'Dampak Kegiatan IUU Fishing Di Indonesia', Seminar Nasional 'Peran dan Upaya Penegak Hukum dan Pemangku Kepentingan Dalam Penanganan dan Pemberantasan IUU Fishing di Wilayah Perbatasan Indonesia' (Kerjasama Kementerian Luar Negeri Republik Indonesia dengan Universitas Airlangga 2014) < https://docplayer.info/30416247-Dampak-kegiataniuu-fishing-di-indonesia.html>.[2].

${ }^{12}$ FAO IPOA-IUU Fishing, FAO International Plan of Action to Prevent, Deter, and Eliminate Illegal, Unreported, and Unregulated Fishing (FAO IPOA-IUU Fishing 2001).
} 
Unreported fishing activities which often occur in Indonesia are generally related to production data. Before now, there were fishing vessels that do not report catches in order to avoid payment of fees. One of the operation modes classified as unreported fishing is the illegal transfer of catches in the middle of seas without reporting to the authorities. This is known as transshipment, and is defined as the process when two fishing vessels meet in the middle of the sea to transfer the fish shipment without reporting to the port for permission and predetermined procedures. This operation was carried in a form of "collaboration" between fishing vessels and the Maritime and Fisheries Service, which sometimes involves foreign ships. Most times these foreign ships act under the guise of Indonesian ships which steals and transfers stolen fishes in Indonesia and other countries.

One case of illegal fish transshipment in Indonesian waters is the arrest of Silver Sea 2, a large capacity fishing vessel owned by a company in Ambon. The arrest of a fish theft mafia at Benjina some time ago turned out to have a connection with the Silver Sea 2. This Thai-flagged boat was caught while stealing fish by illegal transshipment to other ships with a foreign flag in the waters of Arafura and Papua New Guinea.

In this case, the Silver Sea 2 ship was not in possession of a Fishing Vessel Licence (SIKPI)and flew the Indonesian flag to trick the officers. It was caught by the National Army on August 13, 2015, around 80 nautical miles from Weh Island, Sabang, Aceh. The ship occupants refused to be considered as the perpetrator of illegal transshipment even though they were not in possession of the SIKPI. They also sued the Lanal Sabang and Ministry of Maritime Affairs and Fisheries.

Silver Sea Reefer Co. LTD, a Thai company that owns the Silver Sea 2 ship, filed a lawsuit because it was not following criminal law. Its attorney known as Hendri Rivai, said that the pretrial suit was directed to the Indonesian Government cq. Navy Headquarters, cq. Pangmabar and Danlanal Sabang.

Illegal transshipment is a mode of fish theft which is difficult to track since it occurs in the middle of the sea which is unmonitored. According to the international law, the transshipment should go through written reports and export procedures. 
The actions of the Ministry under Minister Susi in eradicating fish theft by catching, burning, and even sinking the vessels have been acknowledged. Although the Silver Sea 2 which was arrested by the Ministry of Maritime Affairs and Fisheries was from other smaller ships, it had a deadweight of almost 3000 tons with an integrated cooling engine.

This huge number of fish theft has left many local fishermen especially in the eastern part of Indonesia with losses owing to illegal vessel drainage of their catches. It is also detrimental to the tax revenue sector ${ }^{13}$ since the official foreign investors should pay some obligations. When fake documents are utilized, many obligations are not fulfilled. The fishing port is one of the factors capable of determining the success of the fishing industry. It functions as a place for fishing vessels to conduct transactions related to their catches.

Based on the above description, the author conducted a research on illegal transshipment in compliance with the Criminal Law No. 45/2009 concerning Fisheries.

This study used a legal research type which examines the object using the law and conceptual approaches. It analyzes the written norms in the legal products from various aspects of its theory and concepts relevant to the object. Furthermore, this study also analyzes the relevant to the object and the illegal transshipment in compliance with Criminal Law in Act Number 45 of 2009 concerning Fisheries.

\section{Illegal Transshipment on Act Number 45 of 2009 Concerning Fisheries}

Some challenges such as the existence of Illegal, Unreported, and Unregulated (IUU) fishing practices arise amid the potential of Indonesian fisheries. The terms of IUU Fishing in Indonesia are contained in PERMA Number 1 of 2007 concerning Fisheries Justice. However, in this study, it refers to understanding issued by the International Plan of Action (IPOA). ${ }^{14}$

\footnotetext{
${ }^{13}$ Direktorat Jenderal PSDKP, The Data of Case of Fishery Boat (Data Kapal Perikanan Pelaku) Illegal Fishing (Direktorat Jenderal PSDKP, KKP 2014).

${ }^{14}$ Food and Agriculture Organisation, International Plan Of Action (IPOA), Deter and Eliminate Illegal, Unreported, Unregulated (IUU) Fishing, Pasal 3.1, Pasal 3.2 Dan Pasal 3.3, Rome (Food and Agriculture Organisation 2001).[24].
} 
IPOA-IUU Fishing has set the limitation on the IUU Fishing definition in a simpler and operational sense. It is defined as a fishing activity which violates the law, and an urgent problem faced by this nation since many resources are stolen by other countries. In addition, some waters in Indonesia have also experienced overfishing. ${ }^{15}$ Regulations regarding IUU Fishing are as follows:

1. International Plan of Action, and Code of Conduct Responsible for Fisheries;

2. Act Number 17 of 1985 concerning Ratification of the United Nations Convention on the Law of the Sea (UNCLOS);

3. Act Number 45 of 2009 amendments to Act Number 31 of 2004 concerning Fisheries;

4. Government Regulation Number 54 of 2002 concerning Fisheries Business;

5. Decree of the Minister of Maritime Affairs and Fisheries Number KEP.50/ MEN/2012 concerning the National Action Plan for Illegal, Unreported, and Unregulated Fishing Prevention and Control in 2012-2016;

6. Regulation of the Minister of Maritime Affairs and Fisheries Number PER.05/ MEN/2008 concerning the Capture Fisheries Business, and

7. PERMA Number 01 of 2007 concerning Fisheries Justice.

Lately, crimes related to fisheries which often occur in Indonesia are illegal transshipment. According to Statistics Agency (BPS) data, by 2011 at least 6,830 fishing vessels in Indonesia were granted fishing permits on EEZ and all of those were required to land their fish inside the country. However, there is still the practice of crimes related to fisheries. Martin Tsamenyi defined illegal transshipment as a mode of fish theft which is carried out through the transfer of fish shipment in the middle of the sea from a local to a foreign ship. These fishes are sold in the high seas without reporting to the authorities. Usually, fishes caught at the end of the permit period were reported, however the number of fishes caught while onboard is no longer carefully re-calculated.

This is a legal study which discusses a product of policy results, as seen from analysis. ${ }^{16}$ This orientation is not only concerned on the broader social impact but

\footnotetext{
${ }^{15}$ Dina Sunyowati and Enny Narwati, Buku Ajar Hukum Laut (Airlangga Press 2013).[163].

${ }^{16}$ D. Fink-Hafner, 'The Political Instrumentalization of Policy Analysis' (2011) 48 Journal Politicka Science Review.[25-39].
} 
also pays attention to the contents of the policy itself. ${ }^{17}$ The content is not only related to the institutional network to create interactions in carrying out this public policy. ${ }^{18}$ Besides, there are other problems related to the content, namely, the placement of a particular policy on the agenda with regards to the period in which the objectives were intended and the formulation in which different possibilities were evaluated. This formulation is closely related to framers while the placement is related to the content of the policy.

Illegal transshipment occurs in the middle of high seas. According to the Business Dictionary, transshipment is the transfer of a shipment from one carrier or more commonly from one vessel to another while in transit. ${ }^{19}$ Although this problem occurred long ago, it was only recently that Silver Sea 2 a large capacity fishing vessel whose agent is owned by one company in Ambon was arrested,. In this case, this ship was not in possession of Fishing Vessel Licence (SIKPI) and also flew the Indonesian flag to deceive the officers. The Silver Sea 2 shipment ship, which was supposed to have a Thai flag, was captured by the Indonesian National Army on August 13, 2015, around 80 nautical miles from Weh Island, Sabang. Fish caught by small fishermen were transferred at the middle of the sea in large quantities. It was very detrimental to the tax sector since payment was not made through the right procedures. Illegal transshipment conducted by Silver Sea 2 is included in a criminal act i.e Embezzlement since it transports and accommodates fish without having a Fishing Vessel Licence (SIKPI). Also, there is no transparency or report related to fish caught which is given to the authorized officer, with the improper application of tax levies.

The legal basis of embezzlement is regulated in Article 372 of the Criminal Code (KUHP). In the Indonesian Dictionary (KBBI), it is defined as a process,

\footnotetext{
${ }^{17}$ Prakoso Bhairawa Putera and Lina Miftahul Jannah, 'Science \& Technology and Innovation Policies in Science \& Technological Research, Development, and Implementation' (2012) 19 Journal of Administrative Science \& Organization.[206-215].

${ }^{18}$ Prakoso Bhairawa Putera, 'Perspektif Sistem Inovasi Dalam Konten Kebijakan Daerah Jawa Timur Bidang Iptek Dan Inovasi, Periode 2000-2011' (2012) 10 Warta Kebijakan Iptek dan Manajemen Litbang.[83-98].

${ }^{19}$ Business Dictionary, 'Definition Transshipment' (Business Dictionary, 2013) <https:// www.businessdictionary.com/definitiontransshipment> accessed 13 December 2020.
} 
method, and act of embezzlement which uses goods illegally. According to R. Soesilo, embezzlement is a crime which is similar to theft in Article 362. However, the difference is that theft is the act of taking possession of goods, while in embezzlement the item is already in the hands of the perpetrator, and is not performed in a criminal way. Furthermore, Lamintang stated that the crime of embezzlement is an abuse of rights or trust by a person which is obtained without any element of unlawfulness. ${ }^{20}$

Juridical understanding of embezzlement is regulated in Chapter XXIV (book II) of the Criminal Code, from 372-376. According to article 372 states "Any person with deliberate intention and unlawfully appropriates to property which wholly or partially belongs to another and in his possession, shall be guilty of embezzlement, and punished with a maximum imprisonment of four years or fine of sixty rupiahs". ${ }^{21}$

Based on the provisions of Article 372 above, legally embezzlement should fulfill the basic elements as follows:

1. Objective elements include the act of possessing someone else's property;

2. Subjective elements include deliberate and illegal embezzlement.

In declaring someone as the perpetrator of embezzlement, it needs to be examined and proven legally and convincingly, both subjectively and objectively. This means that in the context of proving subjective elements such as the notion of intentional embezzlement (opzet), it theoretically encompasses the meaning of willen en witens (willing and/or knowing). Similarly, it needs to prove that the offender has the following:

a. It intends to make deliberate embezzlement against the law;

b. " the act of possessing" what belong to them from the onset;

c. "Something" which means things that are owned in the form of goods;

d. "Partially" or "wholly owned by someone else" that the deeds committed/ deviate, misuse the beliefs of others;

e. "Which is within his power not because of crime" means that the item which belonged to its owner was not unlawfully is not an unlawful act, not from the proceeds of crime.

${ }^{20}$ P.A.F. Lamintang, Dasar-Dasar Hukum Pidana Indonesia (Citra Aditya Bakti 2010).[2-3].

${ }^{21}$ Moeljatno, Asas-Asas Hukum Pidana (Rineka Cipta 2008).[59]. 
The subjective and objective offenses described above, makes it is difficult to determine legal facts committed by someone as embezzlement. Many processes need to be proven not only as someone who deliberately masters in the art but the goods possessed by the perpetrators were obtained through illegal acts not stipulated in Article 372 of the Criminal Code. The elements contained in Article 372 cannot be imposed on the act of illegal transshipment since it does not follow the provisions stipulated in SIPI or SIKPI, which states that fishes caught should be kept at the port.

The illegal transshipment is an embezzlement obtained by a person without any unlawful elements and when there is an abuse of rights or trust. This is, however, clearly different from illegal transshipment, which was against the law right from the onset since it violated the provisions stipulated in the SIPI and SIKPI. Therefore, illegal transshipment cannot be combined or included in the embezzlement crime because it is regulated in Act Number 45 of 2009 amendments to Act Number 31 of 2004 concerning Fisheries.

Currently, the transshipment arrangements are usually part of the article in fisheries regulations. One of which is in the Minister of Maritime Affairs and Fisheries Regulation No. 30 of 2012 (PER.30/MEN/2012) concerning Capture Fisheries Business, which was regarding Illegal Transshipment according to article 69 Paragraph (3). This regulation has been revised to the Minister of Maritime Affairs and Fisheries Regulation No. 57 of 2014 (57/PERMEN-KP/2014) concerning Capture Fisheries Business. There are several articles which were revised and deleted in this amendment, including:

1. Provisions in Article 1 number 34 is deleted;

2. The provisions of Paragraph (7) and Paragraph (8) of Article 37 are deleted;

3. Provisions in Article $37 \mathrm{~A}$ are deleted;

4. Provisions in Article $37 \mathrm{~B}$ are deleted;

5. Provisions in Article $37 \mathrm{C}$ are deleted;

6. Provisions for Attachment XVII are deleted. stop.

Therefore, the article provided by the Minister of Maritime Affairs and Fisheries Regulation No. 30 of 2012 concerning Capture Fisheries Businesses are still in force. Article 69 Paragraph (3), which is related to Illegal Transshipment is 
divided based on the context of written languages in various legal science, namely, such as in the implementation of transshipment, fish caught which needs to be landed at the port appointed in SIPI or SIKPI; and, "and not taken abroad".

In addition, article 41 Paragraph (3) of Act Number 45 of the 2009 Amendment of Act Number 31 of 2004 concerning Fisheries stipulates that "Every fishing vessel arrive in a designated port." This article explains the following:

1. Each fishing ship is either boat, canoe, or other floating device which supports its fishing operations, cultivation, transportation, processing, training, and research/exploration;

2. Fisherman carry out activities to catch the fish in waters by any means, including the use of ships to load, transport, store, cool, handle, process and/or preserve fishes;

3. Fishery Port is a place consisting of land and surrounding waters with certain government limits and fisheries business system activities which are used as a place for vessels to dock, anchor, as well as load/unload fishing equipped with shipping safety facilities and support activities.

This article requires that fishes caught needs to be landed at the port that has been determined or as required in SIPI (Fishing License) and SIKPI (Fishing Vessel License). Besides of Article 41, there is also Article 94 on the same act concerning: "Any person who owns or operates a fishing vessel in the fisheries management area of the Republic of Indonesia with its transportation or related activities without having SIKPI (Fishing Vessel License) as referred to Article 28 Paragraph (1) will be sentenced to a maximum of 5 years imprisonment and a maximum fine of IDR 1,500,000,000 (one billion five hundred million rupiah)".

The elements of the article consists of the following:

1. Individual or corporation;

2. The fisheries management area of the Republic of Indonesia in this article shows its sea territory including archipelago and inland waters;

3. SIKPI (Fishing Vessel License) in this article is the written permission that should be owned by every fishing vessel. 
The practice of illegal transshipment is carried out by small boats and vessels owned by a company as relating to Silver Sea 2. Assuming a small boat transfers fish to the Silver Sea 2 without a license (SIKPI), then it is as a criminal offense because it is in line with Article 94. Furthermore, the word "any person" in Act Number 45 of 2009, means before an individual or corporation. This Silver Sea 2 ship is a corporation which carried out fish transportation without SIKPI, therefore, it should be punished with a maximum imprisonment of 5 (five) years and a fine of Rp 1,500,000,000 (one billion five hundred million rupiahs).

However, in case the transshipment carried out by Siver Sea 2 ships are equipped with SIKPI, the authenticity of the license should also be considered. When it is proven that the license used is fake, which may be subject to criminal provisions according to Article 94A which states that "Any person with falsified or use fake SIUP, SIPI and SIKPI as referred to in Article 28A will be sentenced to a maximum of seven years imprisonment with a fine of IDR 3,000,000,000 (three billion rupiahs)".

Furthermore, although the ship is equipped with SIKPI (Fish Transport Vessel Permit), the act of illegal transshipment is still not permitted and prohibited, as stipulated in the provisions of Article 41 of Law Number 45 of 2009 earlier mentioned. This article regulates criminal sanctions, but only in the form of administrative sanctions as in Paragraph (4).

The above paragraph stipulates that a fishing vessel should be equipped with a SIKPI. When this fails to occur, they turn to the use of fake permit, and the criminal is sentenced. Meanwhile, the provisions contained in Article 41 are in the form of orders to fishermen to land their ships at the port. This article also states that basically, there are no criminal sanctions regarding illegal transshipment. The punishment is only in the form of administrative sanctions, as stated in paragraph 4 below:"Anyone who owns or operates a fishing vessel and fails to unload it at the designated port as referred to in Paragraph (3) is subjected to administrative sanctions in the form of a warning, license freeze, or permit revocation". 
Provisions on illegal transshipment of fishes are undergoing a more specific regulation in the Minister of Maritime Affairs and Fisheries Regulation No. 57 of 2014 concerning the second amendment to the regulation Number Per.30/ MEN/2012 and the Capture Fisheries Business. It regulates in Article 37 Paragraph (6) which states that "Every fishing vessel need to land the captured fish at the port appointed in SIPI and SIKPI". The provisions in Article 37 Paragraph (9) also states that "Every ship which does not land the fish caught at the port as referred in Paragraph (2), (3), (4), (5), and (6) are given sanctions in the form of revocation of SIPI and SIKPI".

The extent of Indonesia's right to utilize fish resources contained in the archipelagic seas and the Indonesian Exclusive Economic Zone is shown in Article 3 of the Law of the Sea Convention 1982. This article states that the sovereignty of a coastal country, in addition to covering land and water areas inland, includes a sea route bordering it called the territorial sea. Therefore, the country has full authority to regulate the use of fisheries in the territorial waters, such as in it inland, island and territorial.

Although foreign ships are given the right to cross peacefully, they are not permitted to fish. This is confirmed by the 1982 Law of the Sea Law Article 19 paragraph (2) (i) which states that the crossing of a foreign vessel need to be considered as endangering peace, order, or security of the coastal State when the vessel in the territorial sea carries out any form of fishery activity.

Furthermore, in the case of violations of laws and regulations which occur in coastal countries, territorial sea or waters of a country are in accordance with the sovereignty granted by article 2 of the United Nations Convention on the Law of the Sea (UNCLOS 1982). The country enforces the rules of law applicable to the shipment, when the violation has an impact or disrupts the security of the coastal state.

According to the author, illegal transshipment is a criminal act which violates the provisions contained in the SIKPI. The stipulation states that captured fishes must be landed at a port or base which causes losses to the State. Therefore, having SIKPI as an illegal transshipment is a criminal offense. 
Although there are more specific regulations governing illegal transshipment, there are no strict criminal sanctions. This is in accordance to Act Number 45 of the 2009 Amendment and Law Number 31 of 2004 concerning Fisheries and the Minister of Maritime Affairs and Fisheries. It was also in accordance with the Regulation Number 57 of 2014 concerning the Second Amendment of the Minister of Maritime Affairs and Fisheries Number Per.30/MEN/2012 Regarding Capture Fisheries Business with only administrative sanctions provided.

\section{The Legal Provision of International Sea}

Substantially, a significant change to the Law of the Republic of Indonesia Number 45 of 2009 compared to Number 31 of 2004 which was previously an emphasis on the provisions of severe criminal sanctions against foreign vessels that commit crimes of fish theft in the Economic Zone. However, these provisions are considered ineffective with weaknesses which include the law itself (legal sustainability), legal apparatus (structural), infrastructure, society, and culture. These weaknesses are described as follows:

1. Weaknesses related to legal substance as explained in the Act Number 31 of 2004 which was revised to Act Number 45 of 2009 concerning fisheries, in a formal juridical manner. There are three agencies authorized to carry out investigations on fisheries criminal offenses in the Indonesian territorial waters i.e Commissioned Officers of the Navy, the National Police, and Civil Servants. The laws do not explicitly regulate the distribution of authority, as well as definite work mechanism arrangements. Therefore, these three agencies are able to declare authority in law enforcement without any system integration in its implementation. This arrangement leads to different interpretations of legislation and differences in the pattern of law enforcement among fellow officers. The issue of the authority is not specifically regulated in the Law on Fisheries.

2. Weaknesses related to human resources of law officers. There are several weaknesses of officials as individuals and institutions, namely, the questioned intellectual aspects that encourage and result in professionalism (especially in law enforcement) and have not been able to follow the development of laws and regulations that tends to be dynamic.

3. Weaknesses are related to law enforcement facilities in accordance to Indonesia's archipelagic territory in the form of waters. The fishery control vessels are not proportional to the water area that should be monitored which spread from Sabang to Merauke. This situation is becoming increasingly severe for the authorities at sea because patrol facilities are in limited condition. 
4. Other weaknesses are relating to procedures for handling criminal acts in the territorial waters of Indonesia. Law No. 8 of 1981 concerning the Criminal Procedure Code adheres to a system of specialization, differentiation, and compensation, namely distinguishing and applying the division of authority to each institution by clearly separating the duties and powers of investigation, prosecution and investigation.

The scope of criminal acts regulated in Act Number 31 of 2004 amendments in Act Number 45 of 2009 concerning Fisheries do not include corporate and criminal offenses, as well as omission of offense which is mainly carried out by an authorized official in overcoming Illegal Fishing. The complexity of IUUFishing is caused by Indonesian waters, weak security, and small fishermen that are unable to reach its resources in the high sea. Weak security is caused by the lack of owned fleet to maintain water security. Besides, the low reach of fishermen in the high waters makes the resources owned by Indonesia cannot be utilized optimally. The eradication of IUU Fishing is also inhibited by inadequate legal instruments. Law Number 45 of 2009 Amendment to Law Number 31 of 2004 concerning Fisheries. However, no article gives rights in the process of inspection at sea to law enforcement officers.

The formulation of heavy criminal sanctions in the amendment article compared to others has not provided a deterrent effect to the perpetrators of Illegal Fishing. As previously stated, a maximum sentence of imprisonment of 6 (six) years for those who commit fishing without possessing or using SIPI and a maximum of 7 (seven) years for those that carry out fake SIUP, SIPI, SIKPI, with a fine of IDR $20,000,000,000$ (twenty billion rupiah).However, the formulation of sanctions in this law does not regulate the lowest or minimum sanctions, therefore, sanctions are imposed which provides a deterrent effect to the perpetrators. The sanctions for corporations as well as the acts of omission have not been regulated. Besides, subjects or actors regulated in the provisions of the Criminal Law are applied to those that directly engage in illegal fishing or to fishing vessels that carry out illegal transshipment. It has not touched other actors including intellectuals involved such as Corporations, State Officials, Civil Servants, Indonesian NAVY SEAL (TNI/ POLRI), and Ship Owners. Act Number 45 of 2009 Amendments to Act Number 
31 of 2004 concerning Fisheries are connected to research reviewed by the author, with the law enforcement in illegal transshipment far from expectation. This act connects the illegal transshipment with the administrative requirement of ships. According to the author, it is classified a crime because it fulfills the element of unlawfulness, either with or without SIKPI. It is also detrimental to the state in the tax sector since there are no legitimate reports on catches which is later accounted for taxation. The existing regulations are still very weak to arrest perpetrators of fisheries criminal acts, especially illegal transshipment. Furthermore, Act Number 45 of the 2009 amendment to Law Number 31 of 2004 concerning Fisheries is a rule imposed for this crime. Currently, there has been no legal update in line with the spirit of eradicating illegal fishing which increasingly endangers the state.

\section{Conclusion}

In conclusion, the illegal transshipment practice engages some of the elements in the criminal provisions of Article 94 of the Act Number 45 of 2009 Amendments to the Act Number 31 of 2004 concerning Fisheries. When a fishing vessel transfers the shipment in the middle of the sea without having a license called SIKPI, they are sentenced to 5 years imprisonment with a fine of IDR 1,500,000,000. This crime also meets some elements in Article 94A of the same act, which states that when a fishing vessel uses fake licenses like SIUP, SIPI, and SIKPI, they are sentenced to 7 years imprisonment and a fine of IDR 3,000,000,000.00. Besides, it also meets some elements in Article 41, but the sanctions imposed are only administrative. The illegal transshipment has been specifically regulated in the Minister of Maritime Affairs and Fisheries Regulation Number 57 of 2014 (57/PERMEN-KP/2014) concerning Capture Fisheries Business, but no strict criminal sanctions regulated for it. In case the illegal transshipment is performed by foreign fishermen, following the sovereignty granted by Article 2 of the United Nations Convention on the Law of Sea (UNCLOS 1982), which enables coastal countries to enforce the regulation applied in each country. Also, the 1982 Sea Law Convention in Article 19 paragraph (2) (i) states that the crossing of a foreign ship endangers the peace, order, or security 
of the coastal country assuming it carries out any fishing activities. Foreign ships, in applying the right to innocent passage or hak lintas damai should obey all laws and regulations both local and international relating to the prevention of collisions at sea that are generally accepted.

\section{Bibliography}

Agustina Soebachman, Sejarah Nusantara Berdasarkan Urutan Tahun (Surya Media Utama 2014).

Business Dictionary, 'Definition Transshipment' (Business Dictionary, 2013) $<$ https://www.businessdictionary.com/definitiontransshipment $>$ accessed 13 December 2020.

D. Fink-Hafner, 'The Political Instrumentalization of Policy Analysis' (2011) 48 Journal Politicka Science Review.

Dina Sunyowati, Port State Measures Dalam Upaya Pencegahan Terhadap IUU Fishing Di Indonesia, Peran Hukum Dalam Pembangunan Di Indonesia, Liber Amicorum Prof. Dr. Etty R.Agoes,SH.,LLM (Remaja Rosdakarya 2013).

__, 'Dampak Kegiatan IUU Fishing Di Indonesia', Seminar Nasional 'Peran dan Upaya Penegak Hukum dan Pemangku Kepentingan Dalam Penanganan dan Pemberantasan IUU Fishing di Wilayah Perbatasan Indonesia' (Kerjasama Kementerian Luar Negeri Republik Indonesia dengan Universitas Airlangga 2014) <https://docplayer.info/30416247-Dampak-kegiatan-iuu-fishing-diindonesia.html>.

Dina Sunyowati and Enny Narwati, Buku Ajar Hukum Laut (Airlangga Press 2013).

Direktorat Jenderal PSDKP, The Data of Case of Fishery Boat (Data Kapal Perikanan Pelaku) Illegal Fishing (Direktorat Jenderal PSDKP, KKP 2014).

Esty Hayu Dewanty R.K, 'Rules of Origin Sebagai Instrumen Penanganan Praktik Illegal Transhipment' (2012) 7 Yuridika <https://e-journal.unair.ac.id/YDK/ article/view/294>.

FAO, IUU Fishing Dalam Code of Conduct For Responsible Fisheries (FAO 1995).

FAO IPOA-IUU Fishing, FAO International Plan of Action to Prevent, Deter, and Eliminate Illegal, Unreported, and Unregulated Fishing (FAO IPOA-IUU Fishing 2001).

Food and Agriculture Organisation, International Plan Of Action (IPOA), Deter 
and Eliminate Illegal, Unreported, Unregulated (IUU) Fishing, Pasal 3.1, Pasal 3.2 Dan Pasal 3.3, Rome (Food and Agriculture Organisation 2001).

Forum Keadilan, Kejutan Di Bulan April, Forum Nomor 50115-21 (2008).

Gatot Supramono, Hukum Acara Pidana Dan Hukum Pidana Di Bidang Perikanan (Rineka Cipta 2011).

Indonesian Criminal Code 1 of 1946.

Kementerian Kelautan dan Perikanan Republik Indonesia, Laporan Kementerian Kelautan Dan Perikanan Republik Indonesia (Sekretaris Jenderal KKP RI 2014).

KKP, 'Statistik Perikanan Tangkap Perairan Laut' $(K K P)<$ http://statistik.kkp. go.id $>$ accessed 11 December 2021.

Law Number 45 of 2009 concerning Fisheries.

Moeljatno, Asas-Asas Hukum Pidana (Rineka Cipta 2008).

Naskah Akademik Keamanan Nasional Indonesia Aspek Maritime (Mabesal 2006).

P.A.F. Lamintang, Dasar-Dasar Hukum Pidana Indonesia (Citra Aditya Bakti 2010).

Prakoso Bhairawa Putera, 'Perspektif Sistem Inovasi Dalam Konten Kebijakan Daerah Jawa Timur Bidang Iptek Dan Inovasi, Periode 2000-2011' (2012) 10 Warta Kebijakan Iptek dan Manajemen Litbang.

Prakoso Bhairawa Putera and Lina Miftahul Jannah, 'Science \& Technology and Innovation Policies in Science \& Technological Research, Development, and Implementation'(2012) 19 Journal of Administrative Science \& Organization.

Regulation of the Minister of Maritime Affairs and Fisheries Number 57 of 2014 concerning the Second Amendment to the Regulation of the Minister of Maritime Affairs and Fisheries Number Per.30/MEN/2012 Regarding Capture Fisheries Business.

Tommy Sihotang, 'Masalah Illegal, Unregulated, Unreported Fishing Dan Penanggulangannya Melalui Pengadilan Perikanan' (2005) 4 Jurnal Keadilan.

United Nations Convention on the Law of the Sea or UNCLOS (United Nations Convention on the Law of the Sea, 1982). 
Herman: Criminal Law Aspect

--This page is intentionally left blank-- 